\title{
Usulan Perbaikan Penempatan Barang pada Area Pemeriksaan Inbound Gudang Logistik dengan Metode Class Based Storage
}

\author{
Yevita Nursyanti ${ }^{1}$, Habib Rais ${ }^{1}$ \\ ${ }^{I}$ Program Studi Manajemen Logistik Politeknik APP, Jl Timbul No 34 Cipedak, Jakarta, 12630, Indonesia
}

\section{ARTICLE INFORMATION}

Received: May 21, 2021

Revised: June 16, 2021

Available online: June 30, 2021

\section{KEYWORDS}

Class Based Storage Method, Layout, Warehouse

\section{CORRESPONDENCE}

Name: Yevita Nursyanti

E-mail: yevita.nursyanti@gmail.com

\section{A B S T R A C T}

\begin{abstract}
The company runs a business by providing services related to storage and handling of goods in warehouses to its customers, namely PT Semarang Autocom Manufacturing Indonesia Jepara (SAMI-JF) and Tugu (SAMI-TF). Goods from SAMI-JF and SAMI-TF customers have similarities so that checkers often have difficulty identifying and finding items to be inspected. This causes delays in checking goods in the inbound inspection area, resulting in a delay in the putaway process. This study aims to provide suggestions for improving the placement of goods in the inbound inspection area in the logistics warehouse. The method used is the Class Based Storage method. Based on data processing, the results of the proposed improvements are the location of goods placement in the logistics warehouse divided into two groups, namely groups A and B. Goods from SAMI-JF customers use the area from block 1 to block 19, while goods from SAMI-TF customers use blocks 20 to 38 blocks with a total distance of $2593.5 \mathrm{~m}$. The results of the proposal are expected to reduce the occurrence of delays in checking goods in the inbound inspection area and completing putaways.
\end{abstract}

\section{PENDAHULUAN}

Gudang logistik bergerak di bidang contract logistics atau biasa disebut dengan Third Party Logistics (3PL) yang menjalankan bisnisnya dengan memberikan jasa kepada customer terkait penyimpanan dan handling barang di gudang. Gudang logistik ini memiliki customer dari PT Semarang Autocom Manufacturing Indonesia Jepara (SAMI-JF) dan Tugu (SAMI-TF). Gudang logistik menjalankan bisnis tanpa memiliki tanggung jawab untuk mengatur jadwal kedatangan barang dan jadwal pengiriman barang, karena hal tersebut merupakan wewenang dari SAMI sebagai customer dan pemilik barang.

Selama bulan Maret 2020 kedatangan barang sangat fluktuatif sehingga beberapa kali terjadi ketidaktepatan waktu penyelesaian pengecekan kuantitas barang dengan plan yang telah ditentukan. Berdasarkan data perusahaan tahun 2020, barang dari customer SAMI-JF mengalami ketidaktepatan waktu penyelesaian pengecekan barang sebanyak $25 \%$ dari total perencanaan dalam satu bulan. Sedangkan barang dari SAMI-TF mengalami keterlambatan sebanyak $15 \%$ dari total plan pengecekan. Berdasarkan data perusahaan, keterlambatan tersebut diakibatkan karena sulitnya mengidentifikasi dan membedakan barang customer SAMI-JF dan SAMI-TF yang datang. Selain itu, diakibatkan juga karena jadwal kedatangan dan pengiriman yang seluruhnya diatur oleh SAMI sehingga berdampak pada kegiatan penerimaan dan pengiriman barang yang acak.

Dari permasalahan tersebut, maka tujuan penelitian ini untuk mengetahui kondisi aktual tata letak penempatan barang pada area pemeriksaan inbound dan merancang usulan perbaikan tata letak fasilitas area inbound untuk mengatasi permasalahan keterlambatan pengecekan barang pada gudang logistik. 
Keterlambatan waktu pengecekan dapat mengakibatkan permasalahan pada tahap berikutnya. Pengecekan yang belum sesuai dengan plan mengakibatkan penumpukan pengecekan pada shift berikutnya sehingga memerlukan over time untuk meyelesaikannya. Over time tentunya membuat perusahaan harus mengeluarkan cost tambahan untuk membayar karyawan. Dampak permasalahan tersebut tidak hanya pada pengecekan kuantitas barang, melainkan juga pada kegiatan putaway yang tertunda dan harus dilanjutkan pada waktu berikutnya sehingga target penyelesaia tidak dapat tercapai. Berdasarkan data perusahaan tahun 2020, Barang SAMI-JF mengalami keterlambatan proses putaway sebanyak 57\% dari jumlah target kegiatan putaway. Sedangkan SAMI-TF mengalami keterlambatan sebanyak $37 \%$ dari total target kegiatan putaway.

Oleh karena itu, diharapkan dengan adanya pengaturan ulang penempatan barang pada area pemeriksaan (inbound) gudang logistik dapat mempersingkat waktu pengecekan barang sehingga diperoleh aliran barang yang lancar. Selain itu, dapat memperkecil kemungkinan keterlambatan pengiriman barang. Pendekatan pengaturan ulang ini dilakukan dengan metode Class Based Storage yang diharapkan mampu menempatkan barang dengan komoditas yang sama pada lokasi yang berdekatan serta meminimalkan pergerakan dan waktu pengambilan barang. Hal ini menjadi dasar perlu dilakukannya pengaturan ulang penempatan barang.

Penggunaan metode Class Based Storage (CBS) dipilih karena dengan menggunakan metode ini menjadikan pengaturan gudang dirancang lebih fleksibel dari pada metode yang lain yaitu dengan cara membagi tempat penyimpanan menjadi beberapa bagian. Tiap tempat tersebut dapat diisi berdasarkan konsep similarity dan popularity dapat digunakan untuk mengelommpokkan barang oleh beberapa jenis barang yang telah diklasifikasikan berdasarkan jenis maupun ukuran dari barang tersebut.

Menurut [1], Pergudangan memiliki fungsi untuk memaksimalkan utilisasi berbagai sumber daya dalam rangka memenuhi permintaan pelanggan atau memaksimalkan pemenuhan permintaan pelanggan dengan sumber daya yang terbatas. Menurut [2], gudang berfungsi untuk area penyimpanan material yang digunakan untuk proses produksi. Sedangkan menurut [3], gudang dalam arti yang lebih luas yaitu tempat penyimpanan barang baik raw material, work in process, atau finish good. Menurut Richard (2014), mengemukakan bahwa "gudang mempunyai 3 (tiga) fungsi dasar pergudangan yaitu perpindahan (movement) yang meliputi aktivitas penerimaan (receiving), transfer atau penyimpanan (transfer or put away), pengambilan pesanan pelanggan atau penyeleksian pesanan (customer order picking or order selection), cross docking, pengiriman (shipping)" [4].

Menurut [5], gudang dapat dibagi berdasarkan karakteristik material yang disimpan sebagai berikut.

1. Raw material storage, merupakan gudang yang menyimpan bahan baku yang akan digunakan untuk proses produksi.

2. Work in process storage, merupakan gudang yang menyimpan barang setengah jadi yang akan kembali dilakukan proses pengolahan tahap berikutnya.

3. Finished goods storage, merupakan gudang yang menyimpan barang jadi yang akan siap untuk dipasarkan kepada konsumen.

4. Storage for supplies, merupakan gudang yang menyimpan barang pendukung untuk menunjang proses produksi dan membantu melancarkan proses produksi.

5. Finished part storage, merupakan gudang yang menyimpan part-part yang siap dirakit.

6. Salvage storage, merupakan gudang yang menyimpan barang yang telah melalui proses produksi namun salah dalam proses pengerjaanya.

7. Scrap \& waste storage, merupakan barang yang tidak dapat diperbaiki lagi atau kompo nen sisa yang tidak dapat dipakai lagi.

Menurut [6], tata letak adalah suatu rancangan penempatan fasilitas, dengan melalui analisis, hingga membentuk konsep, dan diterapkan dalam sistem penerimaan sampai dengan pengiriman barang kepada pelanggan dengan meminimasi total biaya pengeluaran yang dimungkinkan muncul. Sedangkan menurut [7], bahwa tata letak pabrik mencakup fasilitas yang ada di dalamnya seperti mesin, alat produksi, alat pengangkutan barang, tempat pembuangan sampah, kamar kecil dan alat pengawasan. Tata letak penempatan barang yang baik adalah tata letak yang memungkinkan barang yang tersimpan dapat terjangkau dan jarak pemindahan yang minimum [8]. Menurut [9], pengaturan tata letak juga memiliki manfaat lainnya, yaitu dapat meningkatkan kapasitas area penyimpanan dalam gudang. [10] mengemukakan bahwa tata letak yang baik akan dapat memberikan keuntungan dalam sistem produksi sebagai berikut.

1. Menaikkan output produksi, dan mengurangi waktu tunggu (delay). 
2. Penghematan penggunaan area untuk produksi, gudang, dan service.

3. Penggunaan yang lebih besar dari pemakaian mesin, tenaga kerja, dan/atau fasilitas produksi lainnya.

Menurut [11], penempatan barang adalah kegiatan yang berhubungan dengan berdasarkan apa suatu barang ditempatkan dalam gudang. Menurut Julaian, H dan Handayani N.U (2016) dalam [12], terdapat empat metode dalam kebijakan penempatan barang sebagai berkut.

1. Metode Penyimpanan Acak (Random Storage) Metode ini merupakan penyimpanan yang dilakukan secara acak yang hanya mempertimbangkan jarak terdekat antara tempat penyimpanan dengan lokasi input barang.

2. Metode Penyimpanan tetap (Fixed atau Dedicated Storage)

Metode ini memisahkan item sesuai dengan karakteristiknya. Metode ini memiliki lokasi penyimpanan yang teratur dan terorganisir tetapi kurang efisien dalam penggunaan area, karena memerlukan area yang banyak.

3. Metode Class-Based Storage

Metode ini membagi gudang ke dalam beberapa kelas berdasarkan kesamaan suatu jenis bahan atau material tersebut. Pengelompokan dapat dilakukan dengan metode tertentu, salah satunya dengan metode analisis ABC dan konsep Popularity.

4. Metode Shared Storage

Metode ini membagi gudang dengan mempertimbangkan kurun waktu tertentu. Metode ini cocok untuk produk yang disimpan dengan berbagai macam jenis dan memiliki permintaan yang relative konstan.

Menurut [13], analisis ABC merupakan analisis yang menggunakan prinsip hukum pareto (Pareto's Law) yang memfokuskan pengendalian persediaan kepada barang yang berjumlah sedikit namun bernilai tinggi. Sedangkan menurut [14], prinsip analisis ABC adalah mengklasifikasikan setiap barang berdasarkan tingkat investasi yang diserap dalam inventori. Menurut [15], untuk dapat mencapai tujuan perencanaan tata letak fasilitas dibutuhkan prinsip-prinsip penyimpanan sebagai berikut.

1. Popularity, merupakan prinsip penempatan barang yang dikelompokkan berdasarkan frekuensi perputaran barang atau material.

2. Similarity, merupakan prinsip penempatan barang yang dikelompokkan berdasarkan item atau barang yang memiliki kemiripan atau kesamaan seperti packaging, item, supplier, dan lain-lain.

3. Ukuran, merupakan prinsip yang mengatur penyimpanan barang berdasarkan ukuran barang. Barang- memiliki ukuran sama akan dikelompokkan dan ditempatkan pada area yang sama.

4. Karakteristik, merupakan prinsip penempatan barang berdasarkan karakteristik produk, seperti produk yang mudah rusak, produk yang mempunyai bentuk tidak biasa dan mudah hancur, material berbahaya, barang keamanan, dan kompatibilitas.

5. Pemanfaatan Ruang, merupakan prinsip penempatan barang berdasarkan pemanfaatan ruang seperti konservasi ruang, keterbatasan ruang, aksesibilitas, dan keteraturan.

Menurut [16], Standard Operating Procedure (SOP) merupakan pedoman standar untuk menjalankan operasi dalam melakukan implementasi keputusankeputusan yang telah ditetapkan secara terstruktur dan dapat dipertanggungjawabkan. Menurut [17], SOP memiliki tujuan sebagai berikut.

1. Membuat rekaman aktivitas, serta pengoperasian secara praktis.

2. Menyediakan sebuah informasi yang konsisten.

3. Memudahkan menyaring, menganalisis, dan membuang hal-hal atau pekerjaan yang tidak diperlukan, tidak berkaitan secara langsung dengan prosedur yang sudah ada, dan lain sebagainya.

Menurut [18] terdapat faktor yang dapat mempengaruhi format penulisan SOP, diantaranya.

1. Banyaknya poin-poin keputusan yang harus diambil dalam prosedur.

2. Banyaknya langkah-langkah aktivitas yang harus dikerjakan dalam satu rangkaian prosedur

\section{METODOLOGI}

Jenis data dan teknik pengumpulan data sebagai berikut.

\section{Data Primer}

Data primer merupakan data yang diperoleh dari sumber dengan pengamatan secara langsung yang sifatnya up to date. Adapun Teknik yang dilakukan untuk melakukan pengumpulan data ialah.

\section{Teknik Observasi}

Teknik ini diakukan dengan melakukan pengamatan secara langsung di area pemeriksaan inbound dan area-area terkait lainnya di Warehouse PT Agility 
International. Teknik observasi dilakukan untuk memperoleh informasi secara langsung dari lapangan.

\section{Teknik Komunikasi}

Teknik komunikasi dilakukan dengan melakukan interview dan tanya jawab dengan pihak perusahaan terkait dengan PT Agility International secara umum dan divisi inbound secara khusus. Teknik komunikasi menghasilkan data berupa wawancara dengan pihak perusahaan.

\section{Teknik Dokumentasi}

Dokumentasi dilakukan dengan pengambilan gambar lingkungan kerja dan area-area tertentu di PT Agility International. Dokumentasi di lapangan memberikan hasil data berupa foto kondisi aktual di lapangan.

\section{Data Sekunder}

Data sekunder merupakan data yang diperoleh secara tidak langsung, melainkan melalui perantara, berupa catatan, arsip, atau bukti yang telah ada. Data sekunder yang diperoleh diantaranya adalah :

a. Layout PT Agility International

b. Data supplier

c. Data komoditas produk

d. Informasi kedatangan barang (supplier, invoice, keterlambatan).

Pengolahan data dilakukan dengan melakukan identifikasi barang customer yang dianalisis menggunakan metode Class Based Storage untuk mengelompokan dan memisahkan barang, sehingga barang lebih mudah diidentifikasi. Proses pengolahan data dengan metode Class Based Storage sebagai berikut.

\section{Identifikasi Kondisi Aktual}

Kondisi aktual merupakan gambaran keadaan di lapangan. Identifikasi kondisi aktual ini dapat berguna untuk mengetahui kondisi sesungguhnya di lapangan sehingga dapat mempermudah dalam proses penyelesaian masalah. Tahap ini menampilkan layout secara keseluruhan, layout objek yang diteliti, dalam hal ini layout area pemeriksaan inbound, dan SOP penerimaan barang.

\section{Pengelompokan Barang Berdasarkan Similarity}

Pengelompokan barang berdasarkan similarity digunakan untuk mempermudah pencarian barang. Similarity digunakan karena produk dari supplier memiliki kesamaan jenis, ukuran, komoditas, dan lainlain. Konsep ini mengelompokan produk berdasarkan kesamaan tertentu, dalam hal ini mengelompokan produk berdasarkan kesamaan customer, hal ini dapat memudahkan user dalam melakukan identifikasi dan pencarian barang customer yang berbeda.

\section{Pengelompokan Barang Berdasarkan Popularity}

Konsep popularity mengelompokan barang sesuai dengan tingkat atau frekuensi throughput, namun dalam hal ini dapat disederhanakan dengan menggunakan frekuensi kedatangan barang

\section{HASIL DAN PEMBAHASAN}

Gudang logistik bergerak di bidang jasa penyewaan gudang, atau 3PL. Terdapat dua customer yaitu SAMI-TF dan SAMI-JF. Customer tersebut memesan barang dan disimpan di gudang logistik. Barang yang sampai akan ditempatkan pada area pemeriksaan inbound sebelum disimpan di rak. Pemeriksaan barang di area pemeriksaan inbound sering kali terjadi hambatan. Salah satunya adalah sulitnya mencari atau mengidentifikasi barang yang akan dicek. Hal ini menyebabkan tertundanya proses pengecekan dan menyebabkan keterlambatan penyelesaian pengecekan barang, sehingga tidak sesuai dengan target. Tercatat banyak terjadi keterlambatan pengecekan barang selama bulan Maret 2020.

Tabel 1. Keterlambatan Penyelesaian Pengecekan Barang SAMI-JF

\begin{tabular}{clc}
\hline No & Keterangan & Jumlah Pengecekan \\
\hline 1 & Plan & 381 \\
2 & Tidak Terlambat & 305 \\
3 & Terlambat & 75 \\
\hline
\end{tabular}

Sumber : Data Perusahaan (2020)

Tabel 2. Keterlambatan Penyelesaian Pengecekan Barang SAMI-TF

\begin{tabular}{clc}
\hline No & Keterangan & Jumlah Pengecekan \\
\hline 1 & Plan & 478 \\
2 & Tidak Terlambat & 417 \\
3 & Terlambat & 61 \\
\hline
\end{tabular}

Sumber : Data Perusahaan (2020)

Berdasarkan Tabel 1, dapat diketahui bahwa total plan pengecekan sebanyak 381 kali dengan pengecekan yang tidak terlambat sebesar 305 kali dan pengecekan yang terlambat sebesar 75 kali. Apabila dikonversikan ke dalam persen, total keterlambatan penyelesaian pengecekan barang SAMI-JF mencapai $25 \%$. Sedangkan berdasarkan Tabel 2, dapat diketahui bahwa total plan pengecekan sebanyak 478 kali dengan pengecekan yang tidak terlambat sebesar 417 kali dan pengecekan yang terlambat sebesar 61 kali. Apabila dikonversikan ke dalam persen, total keterlambatan penyelesaian pengecekan barang SAMI-TF mencapai 15\%. Dampak yang ditimbulkan akibat keterlambatan pengecekan barang adalah 
tertundanya proses putaway. Berikut adalah tabel penyelesaian putaway barang SAMI-JF dan SAMITF.

Tabel 3. Penyelesaian Putaway Barang SAMI-JF dan SAMI-TF

\begin{tabular}{lcccc}
\hline & $\begin{array}{c}\text { Sesuai } \\
\text { Target }\end{array}$ & $\begin{array}{c}\text { Tidak } \\
\text { Sesuai } \\
\text { Target }\end{array}$ & $\begin{array}{c}\text { Presentase } \\
\text { Tidak Sesuai } \\
\text { Target }(\%)\end{array}$ & $\begin{array}{c}\text { Total } \\
\text { Target }\end{array}$ \\
\hline $\begin{array}{l}\text { SAMI-JF } \\
\text { SAMI- }\end{array}$ & 162 & 219 & 57 & 381 \\
TF & 301 & 177 & 37 & 478 \\
\hline
\end{tabular}

Sumber : Data Perusahaan (2020)

Berdasarkan Tabel 3, dapat diketahui bahwa barang SAMI-JF mengalami 219 kali keterlambatan putaway dari jumlah keseluruhan sebanyak 381. Sedangkan SAMI-TF mengalami 177 kali keterlambatan putaway dari jumlah keseluruhan sebanyak 478. Hal ini mengakibatkan proses putaway harus tertunda dan tidak dapat diselesaikan sesuai dengan target yang telah ditentukan.

\section{Identifikasi Kondisi Aktual}

Area gudang logistik terbagi menjadi dua area utama yaitu Finish Good Export dan Raw Material. Gudang memiliki panjang ke samping secara total 80 meter, dan lebar ke belakang 66 meter. Gudang terbagi menjadi beberapa area salah satunya adalah area pemeriksaan inbound. Area tersebut terletak di sisi paling timur dari gudang dan memiliki satu pintu masuk dari sebelah selatan. Area ini terdapat 38 blok yang digunakan untuk meletakkan barang sementara selama barang dibuka wrappingnya dan melalui proses pengecekan barang.

Berdasarkan Gambar 1, dapat diketahui bahwa area pemeriksaan inbound memiliki ukuran keseluruhan sepanjang 20 meter kali 66 meter. Setiap block memiliki ukuran 17 meter kali 1,5 meter, yang digunakan untuk menyimpan barang sementara ketika melakukan proses pemeriksaan barang. Area inbound memiliki satu pintu masuk untuk melakukan bongkar muat barang dan dua pintu keluar dari area pemeriksaan inbound. Pintu keluar terbagi menjadi dua karena digunakan untuk barang dari customer yang berbeda. Area ini memiliki 38 line blok pengecekan. Line pengecekan berjajar sepanjang 57 meter, setiap line memiliki ukuran yang sama, yaitu dengan panjang ke timur 17 meter dan lebar ke utara 1,5 meter.

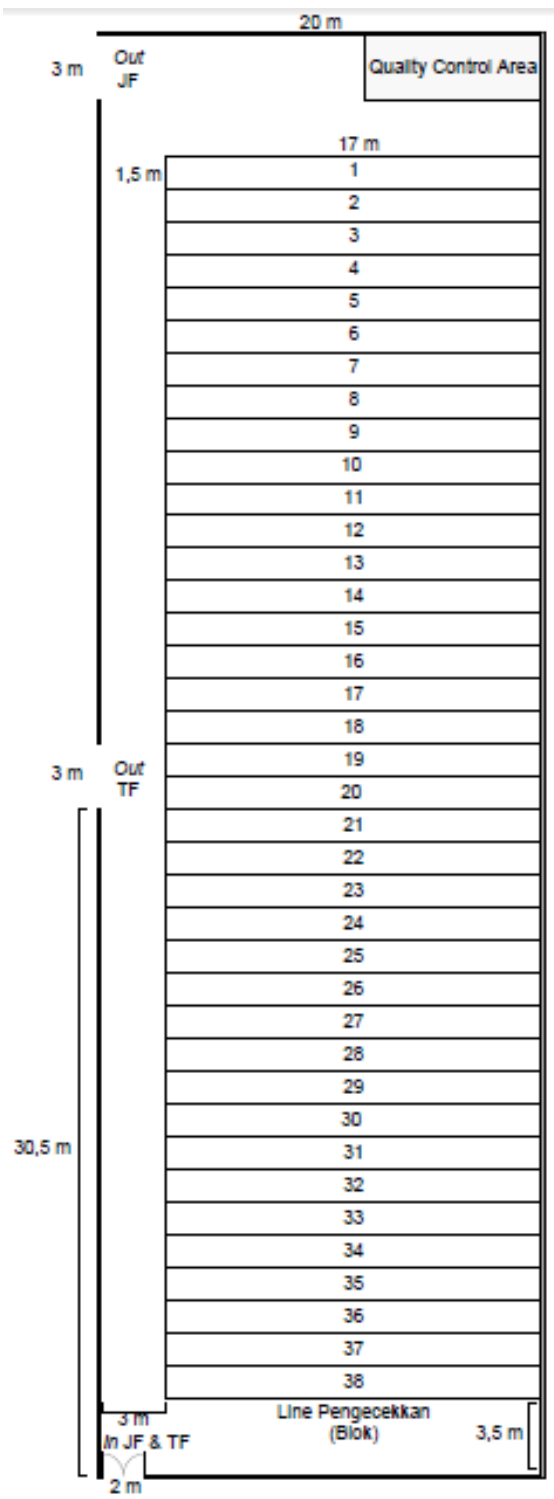

Gambar 1. Tata Letak Aktual Area Inbound Gudang Logistik

\section{Pembagian Kelompok Area Berdasarkan Similarity}

Pengelompokan item diatur berdasarkan konsep similarity yaitu kesamaan customer dari item-item yang digunakan untuk mempermudah mengidentifikasi dan membedakan setiap item yang dikirim oleh supplier ataupun barang yang berada pada area pemeriksaan inbound. Kesamaan-kesamaan yang ada diantaranya kesamaan bentuk, kesamaan supplier, kesaamaan kemasan, dan lain-lain.

Tabel 4. Jumlah Invoice Bulan Januari s.d. Maret

\begin{tabular}{lccccc}
\hline Customer & Jan & Feb & Mar & Total & Presentase \\
\hline SAMI-JF & 405 & 350 & 478 & 1233 & $50 \%$ \\
SAMI-TF & 416 & 438 & 381 & 1235 & $50 \%$ \\
\hline
\end{tabular}

Sumber : Data Perusahaan (2020)

Tabel 4 menunjukkan bahwa kedua customer memiliki pesanan dan kedatangan barang yang sangat berfluktuasi dan tidak tentu setiap bulannya. Hal ini 
dikarenakan kedatangan barang diatur oleh customer itu sendiri. Berdasarkan Tabel 4 juga menunjukkan bahwa dalam tiga bulan pengamatan, kedua supplier memiliki pesanan yang hampir sama.

Tabel 5. Pembagian Blok Barang SAMI-JF dan SAMI-TF

\begin{tabular}{lcc}
\hline Customer & Jumlah Blok & Presentase \\
\hline SAMI-JF & 19 & $50 \%$ \\
SAMI-TF & 19 & $50 \%$ \\
\hline
\end{tabular}

Sumber : Data diolah

Berdasarkan Tabel 5, dapat diketahui bahwa dari 38 blok yang tersedia di area pemeriksaan inbound dibagi menjadi 2 bagian yang sama besar, sehingga untuk masing-masing barang customer memiliki 19 blok. Hal tersebut ditentukan setelah pengamatan selama tiga bulan yang cenderung memiliki presentase pesanan yang sama, walaupun pesanan setiap bulan selalu berbeda dan tidak menentu.

Lokasi penyimpanan di gudang dari kedua customer juga dipisah dengan jumlah rak yang sama banyak. Perhitungan dilakukan dengan melakukan permodelan perhitungan jarak yang ditempuh dari pintu in dan pintu out ke masing-masing blok yang tersedia. Model perhitungan ini merupakan kemungkinan yang dapat terjadi dengan ketentuan 19 blok sama banyak. Model perhitungannya sebagai berikut.

Model 1 Menempatkan SAMI-JF di Blok 1 s.d 19 dan SAMI-TF di Blok 20 s.d 38

Perhitungan Tabel 6 merupakan perhitungan jarak tempuh SAMI-JF apabila ditempatkan di blok 1 s.d 19, yaitu menghasilkan jarak total sebesar 1605,5 meter. Selanjutnya adalah perhitungan jarak tempuh pada barang SAMI-TF di blok 20 s.d 38 dapat dilihat pada tabel 7 .

Tabel 6. Perhitungan Jarak Tempuh SAMI-JF Model 1

\begin{tabular}{lclcc}
\hline Pintu in & $\begin{array}{c}\text { Jarak } \\
(\mathbf{m})\end{array}$ & Pintu out & $\begin{array}{c}\text { Jarak } \\
(\mathbf{m})\end{array}$ & $\begin{array}{c}\text { Total } \\
\text { Jarak }\end{array}$ \\
\hline Blok 1 & 69,25 & Blok 1 & 15,25 & 84,5 \\
Blok 2 & 67,75 & Blok 2 & 16,75 & 84,5 \\
Blok 3 & 66,25 & Blok 3 & 18,25 & 84,5 \\
Blok 4 & 64,75 & Blok 4 & 19,75 & 84,5 \\
Blok 5 & 63,25 & Blok 5 & 21,25 & 84,5 \\
Blok 6 & 61,75 & Blok 6 & 22,75 & 84,5 \\
Blok 7 & 60,25 & Blok 7 & 24,25 & 84,5 \\
Blok 8 & 58,75 & Blok 8 & 25,75 & 84,5 \\
Blok 9 & 57,25 & Blok 9 & 27,25 & 84,5 \\
Blok 10 & 55,75 & Blok 10 & 28,75 & 84,5 \\
Blok 11 & 54,25 & Blok 11 & 30,25 & 84,5 \\
Blok 12 & 52,75 & Blok 12 & 31,75 & 84,5 \\
\hline
\end{tabular}

\begin{tabular}{ccccc}
\hline Pintu in & $\begin{array}{c}\text { Jarak } \\
(\mathbf{m})\end{array}$ & Pintu out & $\begin{array}{c}\text { Jarak } \\
(\mathbf{m})\end{array}$ & $\begin{array}{c}\text { Total } \\
\text { Jarak }\end{array}$ \\
\hline Blok 13 & 51,25 & Blok 13 & 33,25 & 84,5 \\
Blok 14 & 49,75 & Blok 14 & 34,75 & 84,5 \\
Blok 15 & 48,25 & Blok 15 & 36,25 & 84,5 \\
Blok 16 & 46,75 & Blok 16 & 37,75 & 84,5 \\
Blok 17 & 45,25 & Blok 17 & 39,25 & 84,5 \\
Blok 18 & 43,75 & Blok 18 & 40,75 & 84,5 \\
Blok 19 & 42,25 & Blok 19 & 42,25 & 84,5 \\
\cline { 1 - 3 } Total & 1059,25 & Total & 546,25 & \\
\cline { 1 - 3 } Jarak Total & $\mathbf{1 6 0 5 , 5}$ \\
\cline { 1 - 3 }
\end{tabular}

Sumber : Data diolah

Perhitungan Tabel 7 merupakan perhitungan jarak tempuh SAMI-TF apabila ditempatkan di blok 19 s.d 38, yaitu menghasilkan jarak total sebesar 988 meter.

Tabel 7. Perhitungan Jarak Tempuh SAMI-TF Model 1

\begin{tabular}{ccccc}
\hline Pintu in & $\begin{array}{c}\text { Jarak } \\
(\mathbf{m})\end{array}$ & Pintu out & $\begin{array}{c}\text { Jarak } \\
(\mathbf{m})\end{array}$ & $\begin{array}{c}\text { Total } \\
\text { Jarak }\end{array}$ \\
\hline Blok 20 & 40,75 & Blok 20 & 11,25 & 52 \\
Blok 21 & 39,25 & Blok 21 & 12,75 & 52 \\
Blok 22 & 37,75 & Blok 22 & 14,25 & 52 \\
Blok 23 & 36,25 & Blok 23 & 15,75 & 52 \\
Blok 24 & 34,75 & Blok 24 & 17,25 & 52 \\
Blok 25 & 33,25 & Blok 25 & 18,75 & 52 \\
Blok 26 & 31,75 & Blok 26 & 20,25 & 52 \\
Blok 27 & 30,25 & Blok 27 & 21,75 & 52 \\
Blok 28 & 28,75 & Blok 28 & 23,25 & 52 \\
Blok 19 & 27,25 & Blok 19 & 24,75 & 52 \\
Blok 30 & 25,75 & Blok 30 & 26,25 & 52 \\
Blok 31 & 24,25 & Blok 31 & 27,75 & 52 \\
Blok 32 & 22,75 & Blok 32 & 29,25 & 52 \\
Blok 33 & 21,25 & Blok 33 & 30,75 & 52 \\
Blok 34 & 19,75 & Blok 34 & 32,25 & 52 \\
Blok 35 & 18,25 & Blok 35 & 33,75 & 52 \\
Blok 36 & 16,75 & Blok 36 & 35,25 & 52 \\
Blok 37 & 15,25 & Blok 37 & 36,75 & 52 \\
Blok 38 & 13,75 & Blok 38 & 58,25 & 52 \\
\hline Total (m) & 517,75 & Total (m) & 470,25 & \\
\cline { 1 - 2 } Jarak & & 988 & & \\
Total (m) & & & & \\
\hline
\end{tabular}

Sumber : Data diolah

Model 2 Menempatkan SAMI-JF di Blok 20 s.d 38 dan SAMI-TF di Blok 1 s.d 19.

Perhitungan Tabel 8 merupakan perhitungan jarak tempuh SAMI-JF apabila ditempatkan di blok 20 s.d. 38, yaitu menghasilkan total jarak sebesar 1605,5 meter. Selanjtunya adalah perhitungan jarak tempuh pada barang SAMI-TF di blok 1 s.d 19 dapat dilihat pada tabel 9 
Tabel 8. Perhitungan Jarak Tempuh SAMI-JF Model 2

\begin{tabular}{ccccc}
\hline Pintu in & $\begin{array}{c}\text { Jarak } \\
(\mathbf{m})\end{array}$ & Pintu out & $\begin{array}{c}\text { Jarak } \\
(\mathbf{m})\end{array}$ & $\begin{array}{c}\text { Total } \\
\text { Jarak }\end{array}$ \\
\hline Blok 20 & 40,75 & Blok 20 & 43,75 & 84,5 \\
Blok 21 & 39,25 & Blok 21 & 45,25 & 84,5 \\
Blok 22 & 37,75 & Blok 22 & 46,75 & 84,5 \\
Blok 23 & 36,25 & Blok 23 & 48,25 & 84,5 \\
Blok 24 & 34,75 & Blok 24 & 49,75 & 84,5 \\
Blok 25 & 33,25 & Blok 25 & 51,25 & 84,5 \\
Blok 26 & 31,75 & Blok 26 & 52,75 & 84,5 \\
Blok 27 & 30,25 & Blok 27 & 54,25 & 84,5 \\
Blok 28 & 28,75 & Blok 28 & 55,75 & 84,5 \\
Blok 19 & 27,25 & Blok 19 & 57,25 & 84,5 \\
Blok 30 & 25,75 & Blok 30 & 58,75 & 84,5 \\
Blok 31 & 24,25 & Blok 31 & 60,25 & 84,5 \\
Blok 32 & 22,75 & Blok 32 & 61,75 & 84,5 \\
Blok 33 & 21,25 & Blok 33 & 63,25 & 84,5 \\
Blok 34 & 19,75 & Blok 34 & 64,75 & 84,5 \\
Blok 35 & 18,25 & Blok 35 & 66,25 & 84,5 \\
Blok 36 & 16,75 & Blok 36 & 67,75 & 84,5 \\
Blok 37 & 15,25 & Blok 37 & 69,25 & 84,5 \\
Blok 38 & 13,75 & Blok 38 & 70,75 & 84,5 \\
\hline Total (m) & 517,75 & Total (m) & 1087,75 & \\
\cline { 1 - 3 } Jarak & \multicolumn{2}{|l}{} & \\
Total (m) & & 1605,5 & \\
\cline { 1 - 3 } & & &
\end{tabular}

Sumber : Data diolah

Tabel 9. Perhitungan Jarak Tempuh SAMI-TF Model 2

\begin{tabular}{ccccc}
\hline Pintu in & $\begin{array}{c}\text { Jarak } \\
(\mathbf{m})\end{array}$ & $\begin{array}{c}\text { Pintu } \\
\text { out }\end{array}$ & $\begin{array}{c}\text { Jarak } \\
(\mathbf{m})\end{array}$ & $\begin{array}{c}\text { Total } \\
\text { Jarak }\end{array}$ \\
\hline Blok 1 & 69,25 & Blok 1 & 38,25 & 107,5 \\
Blok 2 & 67,75 & Blok 2 & 36,75 & 107,5 \\
Blok 3 & 66,25 & Blok 3 & 35,25 & 107,5 \\
Blok 4 & 64,75 & Blok 4 & 33,75 & 107,5 \\
Blok 5 & 63,25 & Blok 5 & 32,25 & 107,5 \\
Blok 6 & 61,75 & Blok 6 & 30,75 & 107,5 \\
Blok 7 & 60,25 & Blok 7 & 29,25 & 107,5 \\
Blok 8 & 58,75 & Blok 8 & 27,75 & 107,5 \\
Blok 9 & 57,25 & Blok 9 & 26,25 & 107,5 \\
Blok 10 & 55,75 & Blok 10 & 24,75 & 107,5 \\
Blok 11 & 54,25 & Blok 11 & 23,25 & 107,5 \\
Blok 12 & 52,75 & Blok 12 & 21,75 & 107,5 \\
Blok 13 & 51,25 & Blok 13 & 20,25 & 107,5 \\
Blok 14 & 49,75 & Blok 14 & 18,75 & 107,5 \\
Blok 15 & 48,25 & Blok 15 & 17,25 & 107,5 \\
Blok 16 & 46,75 & Blok 16 & 15,75 & 107,5 \\
Blok 17 & 45,25 & Blok 17 & 14,25 & 107,5 \\
Blok 18 & 43,75 & Blok 18 & 12,75 & 107,5 \\
Blok 19 & 42,25 & Blok 19 & 11,25 & 107,5 \\
\cline { 1 - 3 } Total & 1059,25 & Total & 470,25 & \\
\cline { 1 - 2 } Jarak Total & & $\mathbf{1 5 2 9 , 5}$ & & \\
\hline & & & &
\end{tabular}

Sumber : Data diolah
Perhitungan Tabel 9 merupakan perhitungan jarak tempuh SAMI-TF apabila ditempatkan di blok 1 s.d 19, yaitu menghasilkan jarak total sebesar 1529,5 meter. Perhitungan dari model 1 dan model 2 dari masing-masing customer akan direkap dalam satu tabel untuk mempermudah dalam membandingkan jarak tempuh dari kedua model tersebut. Rekapitulasi yang didapatkan dari kedua model perhitungan sebagai berikut.

Tabel 10. Rekapitulasi Perhitungan Jarak Total 2 Permodelan

\begin{tabular}{cccc}
\hline Jenis & SAMI-JF & SAMI-TF & Total \\
\hline Model 1 & 1605,5 & 988 & 2593,5 \\
Model 2 & 1605,5 & 1529,5 & 3135 \\
\hline
\end{tabular}

Sumber : Data diolah

Perhitungan model 1 memiliki jarak tempuh total yang lebih pendek dibandingkan dengan model 2 yaitu sebesar 2593,5 m. Oleh karena itu, dapat dikatakan bahwa perhitungan model 1 menjadi pilihan terbaik dalam menentukan alokasi area barang SAMI-JF dan SAMI-TF. Berdasarkan perhitungan model 1, maka diperoleh pembagian blok sebagai berikut.

Tabel 11. Pembagian Blok Barang SAMI-JF dan SAMI-TF

\begin{tabular}{cccc}
\hline Customer & Presentase & $\begin{array}{c}\text { Jumlah } \\
\text { Blok }\end{array}$ & $\begin{array}{c}\text { Pembagian } \\
\text { Blok }\end{array}$ \\
\hline SAMI-JF & $50 \%$ & 19 & $1-19$ \\
SAMI-TF & $50 \%$ & 19 & $20-38$ \\
\hline
\end{tabular}

Sumber : Data diolah

\section{Pembagian Kelompok Area Berdasarkan Popularity}

Popularity ditentukan berdasarkan frekuensi kedatangan barang. Pada kasus ini, area penempatan barang baik SAMI-JF maupun SAMI-TF selalau berada diantara pintu in dan out, sehingga penempatan kelompok A dan B dari setiap customer tidak memberikan pengaruh terhdadap jarak tempuh. Pembagian kelompok frekuensi kedatangan barang ini dibantu dengan analisis ABC. Analisis ABC dilakukan dengan menghitung frekuensi item dari setiap supplier yang diterima dan dilakukan pengecekan dalam rentan waktu satu bulan, yakni pada bulan Maret. Analisis ABC pada kasus ini tidak menggunakan tiga kelompok $\mathrm{A}, \mathrm{B}$, dan $\mathrm{C}$ namun hanya menggunakan dua kelompok A dan B. Berikut adalah analisis berdasarkan popularity pada barang SAMI-JF pada bulan Maret. 
Tabel 12. Analisis Popularity Barang SAMI-JF pada Bulan Maret

\begin{tabular}{|c|c|c|c|c|c|}
\hline No & Supplier & $\begin{array}{l}\text { Jumlah } \\
\text { Invoice }\end{array}$ & $\begin{array}{c}\text { Presentase } \\
(\%)\end{array}$ & Jumlah & $\begin{array}{c}\text { Presentase } \\
(\%)\end{array}$ \\
\hline 1 & Pasi & 99 & 26 & 99 & 26 \\
\hline 2 & Yazaki Corprotaion & 78 & 20,5 & 177 & 46,5 \\
\hline 3 & Thai Arrow & 34 & 8,9 & 211 & 55,4 \\
\hline 4 & Pemiaw & 30 & 7,9 & 241 & 63,3 \\
\hline 5 & Indowire & 25 & 6,6 & 266 & 69,8 \\
\hline 6 & NMI & 16 & 4,2 & 282 & 74 \\
\hline 7 & PEMI & 15 & 3,9 & 297 & 78 \\
\hline 8 & EMHART & 13 & 3,4 & 310 & 81,4 \\
\hline 9 & Tyco & 10 & 2,6 & 320 & 84 \\
\hline 10 & YGP & 10 & 2,6 & 330 & 86,6 \\
\hline 11 & Hangzhou & 6 & 1,6 & 336 & 88,2 \\
\hline 12 & Yelbl & 4 & 1 & 340 & 89,2 \\
\hline 13 & Yokowo & 4 & 1 & 344 & 90,3 \\
\hline 14 & Arrow & 3 & 0,8 & 347 & 91,1 \\
\hline 15 & Aureole & 3 & 0,8 & 350 & 91,9 \\
\hline 16 & Daiwa & 3 & 0,8 & 352 & 92,7 \\
\hline 17 & Jai & 3 & 0,8 & 356 & 93,4 \\
\hline 18 & Ls Cable & 3 & 0,8 & 359 & 94,2 \\
\hline 19 & Sansho & 3 & 0,8 & 362 & 95 \\
\hline 20 & Tesa & 3 & 0,8 & 365 & 95,8 \\
\hline 21 & Vekasto & 3 & 0,8 & 368 & 96,6 \\
\hline 22 & Mogul & 2 & 0,5 & 370 & 97,1 \\
\hline 23 & Tugu & 2 & 0,5 & 372 & 97,6 \\
\hline 24 & Clux & 1 & 0,3 & 373 & 97,9 \\
\hline 25 & Mochizuki & 1 & 0,3 & 374 & 98,2 \\
\hline 26 & Sai & 1 & 0,3 & 375 & 98,4 \\
\hline 27 & Seien & 1 & 0,3 & 376 & 98,7 \\
\hline 28 & Suai & 1 & 0,3 & 377 & 99,0 \\
\hline 29 & Toms & 1 & 0,3 & 378 & 99,2 \\
\hline 30 & Wako & 1 & 0,3 & 379 & 99,5 \\
\hline 31 & Yamato & 1 & 0,3 & 380 & 99,7 \\
\hline \multirow[t]{2}{*}{32} & YNA & 1 & 0,3 & 381 & 100 \\
\hline & Jumlah & 381 & 100 & & \\
\hline
\end{tabular}

Sumber : Data perusahaan (2020)

Berdasarkan Tabel 12, dapat dikatakan bahwa jenis barang yang relatif sedikit memberikan pengaruh besar terhadap keseluruhan barang.

Tabel 13. Rekapitulasi Analisis Popularity Barang SAMI-JF

\begin{tabular}{ccccc}
\hline Kelompok & $\begin{array}{c}\text { Jumlah } \\
\text { Supplier }\end{array}$ & $\begin{array}{c}\text { Jumlah } \\
\text { Invoice }\end{array}$ & $\begin{array}{c}\text { Presentase } \\
\text { Supplier } \\
(\boldsymbol{\%})\end{array}$ & $\begin{array}{c}\text { Presentase } \\
\text { Nilai } \\
(\boldsymbol{\%})\end{array}$ \\
\hline A & 7 & 297 & 21,9 & 78 \\
B & 25 & 84 & 78,1 & 22 \\
\hline
\end{tabular}

Sumber : Data diolah

Berdasarkan Tabel 13, dapat diketahui bahwa pembagian blok barang dibagi ke dalam 2 kelompok yaitu kelompok A dan kelompok B. Pembagian blok barang dapat dihitung sebagai berikut.
Tabel 14. Pembagian Blok Barang SAMI-JF

\begin{tabular}{cccc}
\hline Kelompok & $\begin{array}{c}\text { Presentase } \\
(\%)\end{array}$ & $\begin{array}{c}\text { Kebutuhan } \\
\text { Blok }\end{array}$ & $\begin{array}{c}\text { Pembagian } \\
\text { Blok }\end{array}$ \\
\hline A & 78 & 15 & $1-15$ \\
B & 22 & 4 & $16-19$ \\
\hline \multicolumn{2}{c}{ Sumber : Data diolah }
\end{tabular}

Pembagian blok tersebut berdasarkan persentase frekuensi kedatangan barang. Persentase tersebut digunakan untuk mencari jumlah blok yang diperlukan yaitu $78 \%$ dari 19 blok merupakan 15 blok, dan $22 \%$ dari 19 adalah 4 blok. Pembagian blok ini tidak memerlukan perhitungan kedekatan dengan pintu in dan out karena setiap blok berada di antara pintu in dan out, sehingga memiliki jarak yang sama. 
Selanjtunya adalah analisis popularity barang SAMI-

TF sebagai berikut.

Tabel 15. Analisis Popularity Barang SAMI-TF pada bulan Maret 2020

\begin{tabular}{|c|c|c|c|c|c|}
\hline No & Supplier & $\begin{array}{l}\text { Jumlah } \\
\text { Invoice }\end{array}$ & $\begin{array}{c}\text { Presentase } \\
(\%)\end{array}$ & Jumlah & $\begin{array}{c}\text { Presentase } \\
(\%)\end{array}$ \\
\hline 1 & Yazaki Coproration & 118 & 31 & 118 & 24,7 \\
\hline 2 & Pasi-AW & 121 & 31,8 & 239 & 50 \\
\hline 3 & Thai Arroq & 40 & 10,5 & 279 & 58,4 \\
\hline 4 & Iwpi & 34 & 8,9 & 313 & 65,5 \\
\hline 5 & Nitto & 32 & 8,4 & 345 & 72,2 \\
\hline 6 & Pemi-Aw & 24 & 6,3 & 369 & 77,2 \\
\hline 7 & Guangzhou & 11 & 2,9 & 380 & 79,5 \\
\hline 8 & Тусо & 9 & 2,4 & 389 & 81,4 \\
\hline 9 & YGP & 9 & 2,4 & 398 & 83,3 \\
\hline 10 & Robert Bosch & 8 & 2,1 & 406 & 84,9 \\
\hline 11 & YGP PTE & 6 & 1,6 & 412 & 86,2 \\
\hline 12 & YGP PTE & 6 & 1,6 & 418 & 87,4 \\
\hline 13 & C-LUX & 5 & 1,3 & 423 & 88,5 \\
\hline 14 & Federal Mogul & 5 & 1,3 & 428 & 89,5 \\
\hline 15 & Kyouei & 5 & 1,3 & 433 & 90,6 \\
\hline 16 & YNA & 5 & 1,3 & 438 & 91,6 \\
\hline 17 & Aureole & 4 & 1 & 442 & 92,5 \\
\hline 18 & Daiwa & 4 & 1 & 446 & 93,3 \\
\hline 19 & DHL & 4 & 1 & 450 & 94,1 \\
\hline 20 & K-Tech & 4 & 1 & 454 & 95 \\
\hline 21 & Tesa Tape & 3 & 0,8 & 457 & 95,6 \\
\hline 22 & Tugu & 3 & 0,8 & 460 & 96,2 \\
\hline 23 & Wako & 3 & 0,8 & 463 & 96,9 \\
\hline 24 & Aptiv Connec & 2 & 0,5 & 465 & 97,3 \\
\hline 25 & Arrow & 2 & 0,5 & 467 & 97,7 \\
\hline 26 & $\begin{array}{l}\text { Artron } \\
\text { Internasional }\end{array}$ & 2 & 0,5 & 469 & 98,1 \\
\hline 27 & Duta Kalingga & 2 & 0,5 & 471 & 98,5 \\
\hline 28 & Emhart & 2 & 0,5 & 473 & 99,0 \\
\hline 29 & Hellermantyton & 1 & 0,3 & 473 & 99,2 \\
\hline 30 & Sansho & 1 & 0,3 & 475 & 99,4 \\
\hline 31 & Seien & 1 & 0,3 & 476 & 99,6 \\
\hline 32 & TDK Singapore & 1 & 0,3 & 477 & 99,8 \\
\hline \multirow[t]{2}{*}{33} & Toyota & 1 & 0,3 & 478 & 100 \\
\hline & Jumlah & 478 & 125,5 & & \\
\hline
\end{tabular}

Sumber : Data Perusahaan (2020)

Tabel 15. menunjukkan bahwa dari keseluruhan 33 supplier, 7 di antaranya memiliki andil hampir $80 \%$ dari keseluruhan.

Tabel 16. Rekapitulasi Analisis Popularity Barang SAMI-TF

\begin{tabular}{ccccc}
$\begin{array}{c}\text { Kelompo } \\
\mathbf{k}\end{array}$ & $\begin{array}{c}\text { Jumlah } \\
\text { Supplier }\end{array}$ & $\begin{array}{c}\text { Jumlah } \\
\text { Invoice }\end{array}$ & $\begin{array}{c}\text { Presentase } \\
\text { Supplier } \\
(\mathbf{\%})\end{array}$ & $\begin{array}{c}\text { Presentase } \\
\text { Nilai } \\
(\boldsymbol{\%})\end{array}$ \\
\hline A & 7 & 380 & 21,2 & 79,5 \\
B & 26 & 98 & 78,8 & 20,5 \\
\hline
\end{tabular}

Sumber : Data diolah
Berdasarkan Tabel 16, dapat diketahui bahwa pembagian blok barang dibagi ke dalam 2 kelompok yaitu kelompok A dan kelompok B. Pembagian blok barang dapat dihitung sebagai berikut yang terlihat pada Tabel 17.

Tabel 17. Pembagian Blok Barang SAMI-TF

\begin{tabular}{cccc}
\hline Kelompok & $\begin{array}{c}\text { Presentase } \\
(\boldsymbol{\%})\end{array}$ & $\begin{array}{c}\text { Kebutuhan } \\
\text { Blok }\end{array}$ & $\begin{array}{c}\text { Pembagian } \\
\text { Blok }\end{array}$ \\
\hline A & 79,5 & 15 & $20-34$ \\
B & 20,5 & 4 & $35-38$ \\
\hline
\end{tabular}

Sumber : Data diolah 
Pembagian blok tersebut berdasarkan persentase frekuensi kedatangan barang. Persentase tersebut digunakan untuk mencari jumlah blok yang diperlukan yaitu $79,5 \%$ dari 19 blok merupakan 15 blok, dan 20,5\% dari 19 adalah 4 blok. Pembagian blok ini tidak memerlukan perhitungan kedekatan dengan pintu in dan out karena setiap blok berada di antara pintu in dan out, sehingga memiliki jarak yang sama.

\section{Usulan Perbaikan}

Perhitungan menggunakan bantuan konsep similarity digunakan untuk membagi kelompok berdasarkan kesamaan customer SAMI-JF dan SAMI-TF. Penempatan barang tersebut memiliki lokasi bloknya masing-masing. Pemilihan lokasi pada blok menggunakan bantuan konsep popularity. Perhitungan popularity dihitung berdasarkan frekuensi barang masuk, dalam hal ini dapat menggunakan supplier sebagai objek perhitungan. Perhitungan ini membagi frekuensi kedatangan barang ke dalam dua kelompok untuk setiap barang customer, pembagian ini disesuaikan dengan jumlah blok yang diperlukan dengan frekuensi kedatangan barang.

Pembagian blok berdasarkan konsep Popularity ditentukan berdasarkan jarak total yang paling minimal. Dalam perhitungan model yang telah dilakukan, model 1 menghasilkan jarak total terendah yaitu sebesar 2593,5m dengan blok pada barang SAMI-JF blok 1 s.d blok 19 dan barang SAMI-TF blok 20 s.d blok 38. Pembagian kelompok lebih jelasnya dapat dilihat pada Tabel 18.

Tabel 18. Rekapitulasi Pembagian Kelompok dan Blok Barang SAMI-JF dan SAMI TF

\begin{tabular}{|c|c|c|c|}
\hline SAMI-JF & Kelompok A & $\begin{array}{l}\text { Pasi, Yazaki Corprotaion, Thai Arrow, } \\
\text { Pemiaw, Indowire, NMI, PEMI, }\end{array}$ & $1-15$ \\
\hline \multirow{3}{*}{ SAMI-TF } & Kelompok B & $\begin{array}{l}\text { EMHEART, Tyco, YGP, Hangzhou, Yelbl, } \\
\text { Yokowo, Arrow, Aureole, Daiwa, Jai, Ls } \\
\text { Cable, Sansho, Tesa, Velasto, Mogul, Tugu, } \\
\text { Clux, Mochizuki, Sai, Seien, Suai } \\
\text { Toms, Wako, Yamato, YNA }\end{array}$ & $16-19$ \\
\hline & Kelompok A & $\begin{array}{l}\text { Yazaki Coproration, Pasi-Aw, Thai Arroq, } \\
\text { Iwpi, Nitto, Pemi-Aw, Guangzhou }\end{array}$ & $20-34$ \\
\hline & Kelompok B & $\begin{array}{l}\text { Tyco, YGP, Robert Bosch, YGP PTE, YGP } \\
\text { PTE, C-LUX, Federal Mogul, Kyouei, } \\
\text { YNA, Aureole, Daiwa, DHL, K-Tech, Tesa } \\
\text { Tape, Tugu, Wako, Aptiv Connec, Arrow, } \\
\text { Artron Internasional, Duta Kalingga, } \\
\text { Emhart, Hellermantyton, Sansho, Seien, } \\
\text { TDK Singapore (PTE), Toyota }\end{array}$ & $35-38$ \\
\hline
\end{tabular}

Sumber : Data diolah

\section{KESIMPULAN}

Berdasarkan hasil pengolahan usulan penempatan barang pada area pemeriksaan inbound di gudang logistik, dapat disimpulkan bahwa berdasarkan pengolahan data menggunakan Class Based Storage barang dapat dikelompokkan berdasarkan konsep similarity dan popularity. Lokasi penempatan di gudang logistik terbagi ke dalam dua kelompok yaitu kelompok A dan B. SAMI-JF menggunakan area dari blok 1 sampai dengan blok 19, sedangkan SAMI-TF menggunakan blok 20 sampai dengan blok 38 dengan jarak total sebesar 2593,5 m.
Hasil perhitungan perencanaan usulan perbaikan dengan menggunakan metode Class Based Storage diharapkan dapat memberikan pemanfaatan ruang yang lebih efektif serta menyediakan ruang penyimpanan yang lebih teratur. Usulan penempatan jarak yang lebih pendek juga dapat memberikan manfaat memberikan efisiensi penggunaan material handling yang digunakan dan dapat menyediakan fleksibilitas ruang yang maskimum. Jarak tempuh yang lebih singkat diharapkan dapat mempersingkat waktu yang dibutuhkan dalam melakukan pengecekan barang, sehingga diharapkan keterlambatan dapat berkurang. 


\section{DAFTAR PUSTAKA}

[1] J. Johan and K. Suhada, "Usulan Perancangan Tata Letak Gudang dengan Menggunakan Metode Class-Based Storage (Studi Kasus di PT Heksatex Indah, Cimahi Selatan)," J. Integr. Syst., vol. 1, no. 1, pp. 52-71, 2018.

[2] H. Juliana and N. U. Handayani, "Peningkatan Kapasitas Gudang dengan Perancangan Layout Menggunakan Metode Class-Based Storage,"J@ti Undip J. Tek. Ind., vol. 11, no. 2, p. 113, 2016.

[3] M. G. Yunanto, Holy Icun; Santika, Business Concepts Implementation Series in Inventory Management. Jakarta: Elex Media Komputindo, 2005.

[4] C. Makatengkeng, A. H. Jan, J. S. B. Sumarauw, and J. S. B. Sumarauw, "Analisis Sistem Manajemen Pergudangan pada PT Timur Laut Jaya Manado," J. EMBA J. Ris. Ekon. Manajemen, Bisnis dan Akunt., vol. 7, no. 4, pp. 5924-5933, 2019.

[5] A. N. Hakim, Perancangan Ulang Layout Ruang Penyimpanan Sampel Stabilitas Impermeable Berdasarkan Konsep Similarity dan Popularity serta Prinsip 5S (Studi Kasus di PT FPP). 2018.

[6] S. Pandiangan, Operasional Managemen Pergudangan. Jakarta: Mitra Wacana Media, 2017.

[7] T. H. Subagyo, Pangestu; Asri, Marwan; Handoko, Dasar-Dasar Operations Research, Edisi ke-2. Yogyakarta: BPFE, 1993.

[8] S. N. Karonsih, N. W. Setyanto, and C. F. M. Tantrika, "Perbaikan Tata Letak Penempatan Barang di Gudang Penyimpanan Material Berdasarkan Class Based Storage Policy (Studi Kasus : Gudang Material PT Filtrona Indonesia - Surabaya)," J. Rekayasa dan Manaj. Sist. Ind., vol. 1, no. 2, pp. 345-357, 2013.

[9] W. Setyawan and F. R. Fauzi, "Efektivitas Tata Letak Gudang Baru untuk Menekan Tingkat Kerusakan Produk Menggunakan Metode Class Based Storage," J. Media Tek. dan Sist. Ind., vol. 4, no. 2, p. 100, 2020.

[10] J. M. Apple, Tata Letak Pabrik dan Pemindahan Bahan, Edisi ke-3. Bandung: ITB, 1990.

[11] N. P. A. Hidayat, "Perancangan Tata Letak Gudang dengan Metoda Class-Based Storage Studi Kasus CV SG Bandung," J. Al-AZHAR Indones. SERI SAINS DAN Teknol., vol. 1, no. 3, p. 105, 2012.

[12] Basuki and M. Hudori, "Implementasi Penempatan dan Penyusunan Barang di Gudang Finished Goods Menggunakan Metode Class Based Storage," Ind. Eng. J., vol. 5, no. 2, pp. 11-16, 2016.

[13] B. . Russel, R.S; Taylor, Operations Management, Edisi ke-7. USA: John Wiley \& Sons, Inc, 2011.
[14] M. H. Kusnawan, D. D. Damayanti, and B. Santosa, "Usulan Perancangan Alokasi Penyimpanan Produk Menggunakan Kebijakan Class Based Storage Untuk Mengurangi Waktu Delay Pada Gudang Bm PT XYZ Bandung Storage Allocation Design for Products Using Class Based Storage Policy To Reduce Delay Time in Bm Pt . Xy," vol. 2, no. 2, pp. 4108-4115, 2015.

[15] J. A. Tompkins, James A.; White, Facilities Planning, Fourth Edi. USA: Wiley, 2010.

[16] H. Marimin; Tanjung, Hendri; Prabowo, Sistem Informasi Manajemen Sumber Daya Manusia. Jakarta: Grasindo, 2006.

[17] J. D. Santosa, Lebih Memahami SOP (Standar Operating Procedure). Surabaya Kata Pena, 2014.

[18] W. Setiawati, "Penyusunan Standard Operating Procedure (Sop) Pada Pt. Sketsa Cipta Graha Di Surabaya," Agora, vol. 3, no. 1, pp. 514-522, 2015. 